\title{
PENGARUH MODEL PEMBELAJARAN DAN GAYA BELAJAR TERHADAP KEMAMPUAN BERPIKIR KRITIS PESERTA DIDIK KELAS X SMK NEGERI 2 WATAMPONE
}

\author{
Rusnilawarni, Pince Salempa ${ }^{1}$, Muhammad Anwar ${ }^{2}$ \\ ${ }^{1,2}$ DosenPascasarjana Universitas Negeri Makassar, Makassar \\ Email: c_warni@yahoo.co.id
}

\begin{abstract}
ABSTRAK
Penelitian ini bertujuan untuk mengetahui pengaruh model pembelajaran dan gaya belajar terhadap kemampuan berpikir kritis peserta didik pada materi pokok larutan elektrolit dan non elektrolit di kelas X SMK Negeri 2 Watampone. Jenis penelitian adalah eksperimen semu dengan menggunakan desain faktorial $2 \times 3$. Populasi penelitian adalah seluruhpeserta didik kelas X SMK Negeri 2 Watampone tahun ajaran 2014/2015 yang terdiri dari 9 kelas dengan jumlah peserta didik sebanyak 288. Pengambilan sampel dilakukan denganpurposive sampling sebanyak dua kali dan kelas yang terpilih adalah kelas X TITL 1 (Teknik Instalasi Listrik) dan X TITL 2. Hasil análisis statistik deskriptif menunjukkan bahwa Rata-rata kemampuan berpikir kritis peserta didik yang diajar dengan model pembelajaran inkuiri dan model pembelajaran kooperatif tipe artikulasi masing-masing 75.78 dan 66.40. Rata-rata kemampuan berpikir kritis peserta didik yang memiliki gaya belajar kinestetik, visual dan auditori berturut-turut yaitu 73.34, 65.00 dan 63.15. Pengujian hipotesis dilakukan dengan program SPSS 20 menggunakan analisis two way Anova. Hasil penelitian ini menunjukkan bahwa (1)Tidak ada pengaruh model pembelajaraninkuiri dan model pembelajaran kooperatif tipe Artikulasi terhadap kemampuan berpikir kritis peserta didik di kelas X SMK Negeri 2 Watampone pada materi pokok larutan elektrolit dan non elektrolit.(2)Ada pengaruh gaya belajar kinestetik, visual dan auditorialterhadap kemampuan berpikir kritis peserta didik di kelas X SMK Negeri 2 Watampone pada materi pokok larutan elektrolit dan non elektrolit, (3) Ada pengaruh interaksi antara model pembelajaran dan gaya belajar terhadap kemampuan berpikir kritis peserta didik pada materi pokok ikatan kimia di kelas X SMK Negeri 2 Watampone. Hasil Uji Tukey HSD menunjukkan bahwa kemampuan berpikir kritis peserta didik yang memiliki gaya belajar kinestetik lebih tinggi daripada peserta didik yang memiliki gaya belajar visual dan auditori, sedangkan peserta didik yang memiliki gaya belajar visual dan auditori kemampuan berpikir kritisnya tidak berbeda.
\end{abstract}

Kata kunci: model pembelajaran, gaya belajar, kemampuan berpikir kritis.

\begin{abstract}
This research aims to identify the influence of interaction instructional model and learning style to critical thinking ability of students in class X SMK Negeri 2 Watampone in electrolyte and nonelectrolyte solution. The type of research is quasi-experimental using factorial design $2 \times 3$. Population of the research is all of studentsin class X SMK Negeri 2 Watampone school year 2014/2015 consist of 9 class, which amounted to 288 students. The sample is taken by twice of purposive sampling, and the selected classesis X TITL 1 (electric installation technique) and X TITL 2. The Hypothesis test is conducted by SPSS 20 Program using two way Anova. The results of descriptive statistic are average critical thinking ability that students taught using inquiry learning model and cooperative tipe articulation learning are 75.78 and 66.40. Average score critical thinking ability of learners who have learning styles kinethetic, visual and auditory are 73.34, 65.00 and 63.15. The results of this study show that (1) There is no influence of instructional model to critical thinking abilityof students in class
\end{abstract}


X SMK Negeri 2 Watampone in electrolyte and non electrolyte solution, (2) There is no influence of visual learning style, auditory and kinesthetic toward the critical thinking abilityof students in class X SMK Negeri 2 Watampone in electrolyte and non electrolyte solution, (3) There is an interaction between the instructional model and learningstyles in influencing the critical thinking ability of students in class X SMK Negeri 2 Watampone in electrolyte and non electrolyte solution. Tukey HSD test result show that critical thinking ability of learners who have learning styles kinesthetic higher than the learners who have visual and auditory learning styles, and than critical thinking ability of learners who have learning styles visual and auditory learning style is not different.

Key words: instructional model, learning style, critical thinking ability.

\section{PENDAHULUAN}

Penyelenggaraan peningkatan mutu pendidikan pada berbagai jenis dan jenjang untuk mencapai tujuan pendidikan nasional senantiasa dilakukan perbaikan.Salah satunya adalah peningkatan kemampuan pemecahan masalah peserta didik.Kemampuan pemecahan masalah pada peserta didik sejalan dengan peningkatan kemampuan berpikir kritis dan kreatif.Hasil penelitian Hasruddin (2009), menunjukkan bahwa peserta didik yang terbiasa menggunakan kemampuan berpikir kritis dapat lebih cermat dalam membedakan dan memahami pendapat orang lain yang mungkin berbeda atau sama, dengan mengetahui pertentangan tersebut maka peserta didik menjadi tidak pernah ragu dalam pengambilan keputusan.

Berbagai cara dilakukan untuk meningkatkan kemampuan berpikir kritis, salah satunya dalam proses pembelajaran. Pembelajaran tidak akan berlangsung jika tidak ada guru sebagai pengajar.Guru dalam membuat suatu perencanaan pembelajaran harus mampu untuk memilih dan menetukan model pembelajaran yang sesuai dengan materi yang diajarkan. Sebagai pengajar, guru memiliki gaya mengajar yang berbedabeda, tetapi guru harus mampu menyesuaikan lingkungan pembelajaran dengan kondisi peserta didik sehingga terjadi interaksi yang positif antara guru dan peserta didik (Pritchard, 2009). Interaksi positif ini salah satunya dapat dicapai dengan memahami karateristik peserta didik.Hal ini karena setiap peserta didik memiliki karateristik yang berbeda (Gufron, 2010).

Saat proses pembelajaran berlangsung tidak semua peserta didik dapat memahami pelajaran dengan mudah, ada peserta didik yang dengan mudah memahami dan adapula yang mengalami kesulitan ketika pelajaran berlangsung (Gufron, 2010). Salah satu penyebab terjadinya hal ini adalah karena adanya perbedaan gaya belajar yang dimiliki oleh masing-masing peserta didik. Gaya belajar merupakan kecenderungan peserta didik untuk mengadaptasi strategi tertentu dalam belajarnya sebagai bentuk tanggung jawabnya untuk mendapatkan satu pendekatan belajar yang sesuai dengan tuntutan belajar di kelas/sekolah maupun tuntutan dari mata pelajaran (Slameto, 2003).

Ada banyak perbedaan dalam gaya belajar, tiga gaya belajar paling populer yang digunakan peserta didik dalam mengambil informasi adalah gaya belajar visual, auditori, dan kinestetik (Gilakjani, 2012). Gaya belajar visual adalah kecenderunganpeserta didik mengandalkan peranan penting penglihatan dalam proses pembelajaran. Gaya belajar auditorial adalah kecenderungan peserta didik mengandalkan peranan pentingpendengaran dalam proses pembelajaran. Gaya belajar kinestetik adalah kecenderungan peserta didik mengandalkan peranan penting gerakan dan sentuhan dalam proses pembelajaran (Pritchard, 2009\&De Porter, 1992).

Berdasarkan hasil observasi yang dilakukan khususnya di SMK Negeri 2 
Watampone, dalam menentukan model pembelajaran yang dilakukan dalam proses pembelajaran belummemperhatihan faktor gaya belajar peserta didik. Hasil belajar peserta didik pada mata pelajaran adapatif khusus kimia masih rendah, namun pada mata pelajaran produktif masih terdapat peserta didik yang memiliki hasil belajar dibawah ketuntasan.Hal ini menunjukkan bahwa tidak semua peserta didik memahami materi pelajaran melalui praktek secara langsung, peserta didik memiliki kebutuhan yang berbeda dalam menerima pembelajaran, dalam hal ini berkaitan dengan gaya belajar peserta didik tersebut. Gaya belajar peserta didik juga memberikan pengaruh pada kemampuan berpikir kritis mereka.

\begin{tabular}{lrrr}
\multicolumn{2}{r}{ Berdasarkan hal tersebut dipandang } \\
perlu untuk menerapkan & model \\
pembelajaran yang dapat melatih
\end{tabular}
kemampuan berpikir kritis peserta didik. Dimana pemilihan model pembelajaran juga memperhatikan faktor gaya belajar peserta didik.

Model pembelajaran inkuiri merupakan salah satu model pembelajaran yang dapat membantu meningkatkan kemampuan berpikir kritis peserta didik. Melalui pembelajaran ini, peserta didik mempunyai kesempatan yang luas untuk mencari dan menemukan sendiri apa yang dibutuhkannya. Pembelajaran inkuiri merupakan proses untuk memperoleh dan mendapatkan informasi dengan melalui observasi atau eksprimen untuk mencari jawaban atau memecahkan masalah terhadap pertanyaan atau rumusan masalah dengan bertanya atau mencari tahu (Suyanti, 2007).

Terdapat lima prinsip penggunaan inkuiri yaitu berorientasi pada pengembangan intelektual, prinsip interaksi, prinsip bertanya, prinsip belajar untuk berpikir dan prinsip keterbukaan (Sanjaya, 2006). Adapun sintaks dari model pembelajaran inkuiri sebagai berikut:

Tabel 1 Sintaks/ Tahap Model Pembelajaran Inkuiri Terbimbing

\begin{tabular}{|c|c|}
\hline Fase & Perilaku guru \\
\hline 1. $\quad$ Orientasi & $\begin{array}{l}\text { Guru meransang peserta didik untuk berpikir } \\
\text { memecahkan masalah. Beberapa hal yang } \\
\text { dapat guru lakukan dalam tahapan orientasi }\end{array}$ \\
\hline
\end{tabular}

\begin{tabular}{|c|c|c|}
\hline & & $\begin{array}{l}\text { adalah (1) menjelaskan topik, tujuan dan hasil } \\
\text { belajar yang diharapkan dicapai oleh peserta } \\
\text { didik (2) Menjelaskan pokok-pokok kegiatan } \\
\text { untuk mencapai tujuan (3) menjelaskan } \\
\text { pentingnya topik dan kegiatan belajar sebagai } \\
\text { motivasi bagi peserta didik. }\end{array}$ \\
\hline 2. & $\begin{array}{l}\text { Merumuskan } \\
\text { masalah }\end{array}$ & $\begin{array}{l}\text { Langkah ini membawa peserta didik pada } \\
\text { suatu persoalan yang mengandung teka-teki. } \\
\text { Persoalan yang disajikan adalah persoalan } \\
\text { yang menantang berpikir. }\end{array}$ \\
\hline 3. & $\begin{array}{l}\text { Merumuskan } \\
\text { hipotesis }\end{array}$ & $\begin{array}{l}\text { Salah satu cara yang dapat dilakukan guru } \\
\text { untuk mengembangkan kemampuan } \\
\text { berhipotesis pada peserta didik adalah dengan } \\
\text { mengajukan pertanyaan yang dapat } \\
\text { mendorong peserta didik untuk dapat } \\
\text { merumuskan berbagai perkiraan kemungkinan } \\
\text { jawaban dari suatu permasalahan. }\end{array}$ \\
\hline 4. & $\begin{array}{l}\text { Mengumpul } \\
\text { kan data }\end{array}$ & $\begin{array}{l}\text { Proses pengumpulan data membutuhkan } \\
\text { motivasi yang kuat dalam belajar, ketekunan } \\
\text { dan kemampuan menggunakan potensi } \\
\text { berpikirnya. Tugas guru dalam tahap ini } \\
\text { adalah mengajukan pertanyaan yang dapat } \\
\text { mendorong peserta didik untuk berpikir } \\
\text { mencari informasi yang dibutuhkan. }\end{array}$ \\
\hline 5. & $\begin{array}{l}\text { Menguji } \\
\text { hipotesis }\end{array}$ & $\begin{array}{l}\text { Proses ini menentukan jawaban yang } \\
\text { dianggap diterima sesuai data atau informai } \\
\text { yang diperoleh berdasarkan pengumpulan data } \\
\text { sehingga guru dapat mengembangkan } \\
\text { kemampuan berpikir rasional peserta didik. }\end{array}$ \\
\hline 6. & $\begin{array}{l}\text { Membuat } \\
\text { kesimpulan }\end{array}$ & $\begin{array}{l}\text { Proses mendeskripsikan temuan yang } \\
\text { diperoleh berdasarkan hasil pengujian } \\
\text { hipotesis, untuk memperoleh kesimpulan yang } \\
\text { akurat sebaiknya } \\
\text { guru mampu menunjukkan pada peserta didik } \\
\text { mana data yang relevan. }\end{array}$ \\
\hline
\end{tabular}

Sumber : Suyanti.2007

Selain model pembelajaran inkuiri juga terdapat model pembelajaran kooperatif tipe artikulasi.Model pembelajaran ini merupakan suatu model pembelajaran kelompok secara berpasangan.Pada model pembelajaran ini peserta didik tidak hanya mendengarkan penjelasan materi dari guru tetapi mendengarkan dari temannya. Penjelasan akan disaksikan dan didengarkan oleh peserta didik secara berulang-ulang, selain itu juga dapat menjelaskan kembali hal yang telah dipahami sehingga peserta didik akan semakin paham dengan materi yang telah dipelajari sehingga akan membantu dalam meningkatkan kemampuan berpikir kritisnya. Adapun sintaks dari model ini adalah sebagai berikut:

Tabel 2 Sintaks/ Tahap Model Pembelajaran Kooperatif Tipe Artikulasi

\begin{tabular}{|c|c|}
\hline Fase & Perilaku guru \\
\hline $\begin{array}{l}\text { Fase } 1 \\
\text { Menyampaikan } \\
\text { kompetensi vang ingin }\end{array}$ & $\begin{array}{lll}\text { Guru mengemukakan } & \text { tujuan } \\
\text { pembelajaran yang ingin dicapai }\end{array}$ \\
\hline dicapai & $\begin{array}{l}\text { pembelajaran yang akan } \\
\text { dilaksanakan. }\end{array}$ \\
\hline $\begin{array}{l}\text { Fase } 2 \\
\text { Guru } \\
\text { materi }\end{array}$ & $\begin{array}{l}\text { Guru menyajikan materi seperti } \\
\text { biasanya yaitu dengan menjelaskan } \\
\text { materi di depan kelas dan memberi } \\
\text { contoh soal. }\end{array}$ \\
\hline $\begin{array}{l}\text { Fase } 3 \\
\text { Membentuk kelompok } \\
\text { secara berpasangan }\end{array}$ & $\begin{array}{l}\text { Guru membentuk kelompok } \\
\text { berpasangan dua orang, untuk } \\
\text { mengetahui daya serap peserta didik }\end{array}$ \\
\hline $\begin{array}{l}\text { Fase } 4 \\
\text { Melakukan diskusi }\end{array}$ & $\begin{array}{lr}\text { Guru mengarahkan peserta didik } \\
\text { untuk }\end{array}$ \\
\hline
\end{tabular}




\begin{tabular}{llr}
\hline secara bergantian & \multicolumn{3}{l}{ menceritakan/menjelaskan kembali } \\
& apa yang mereka pahami dari \\
& penjelasan guru kepada teman \\
& pasangannya, dilakukan secara \\
& bergantian serta sambil membuat \\
& catatan-catatan kecil. & \\
Fase 5 & Guru menungaskan peserta didik \\
Mempersentasikan & secara bergiliran/diacak \\
hasil diskusi & menyampaikan hasil wawancaranya \\
& dengan teman pasangannya. Sampai \\
& sebagian peserta didik sudah \\
& menyampaikan & hasil \\
Fase 6 & wawancaranya. & \\
Membimbing & Guru mengulangi/menjelaskan \\
menyimpulkan & dan & kembali materi yang belum \\
& dipahami peserta didik dan \\
& mengarahkan peserta didik untuk \\
& menyimpulkan materi yang \\
& dipelajari.
\end{tabular}

Sumber: Suyatno, 2009

Materi larutan elektrolit dan non elektrolit merupakan salah satu materi kimia kelas $\mathrm{X}$ yang penyajiannya melibatkan pemahaman konsep dan pengaplikasian yang melibatkan kemampuan berpikir kritis peserta didik dalam menyelesaikan masalah yang berkaitan dengan larutan elektrolit dan non elektrolit. Dalam mengajarkan materi ini, dapat digunakan beberapa model pembelajaran seperti kedua model pembelajaran yang telah dijelaskan sebelumnya. Kedua model pembelajaran ini diharapkan dapat membantu peserta didik agar mampu mengembangkan kemampuan berpikir kritis dan disesuaikan dengan gaya belajarnya. Selain itu, materi larutan elektrolit dan non elektrolit ini juga membahas mengenai aplikasi dalam kehidupan sehari-hari yang ada disekitar peserta didik serta terdapat kegiatan dimana peserta didik merakit sendiri alat uji elektrolit yang akan digunakan. Oleh karena itu, pemilihan kelas ekperimen dalam penelitian ini perlu mengaitkan antara materi larutan elektrolit dan non elektrolit dengan jurusan yang dapat mengaplikasian materi ini secara langsung.

Berdasarkan uraiandiatas, perlu untuk mengetahui bagaimana pengaruh model pembelajaran dan gaya belajar terhadap kemampuan berpikir kritis peserta didik, dengan melakukan sebuah penelitian tentang pengaruh model pembelajaran dan gaya belajar terhadap kemampuan berpikir kritis peserta didik.

Penelitian ini dilakukan untuk menjawab rumusan masalah yaitu "Apakah ada pengaruh model pembelajaran inkuiri dan model pembelajaran kooperatif tipe artikulasi terhadap kemampuan berpikir kritis peserta didik," "Apakah ada pengaruh gaya belajar belajar kinestetik, visual, dan auditori terhadap kemampuan berpikir kritis peserta didik", "Apakah ada pengaruh interaksi antara model pembelajaran dan gaya belajar terhadap kemampuan berpikir kirtis peserta didik."

\section{METODE PENELITIAN}

1. Jenis dan Lokasi Penelitian

Penelitian ini merupakan penelitian eksperimen semu (quasy eksperiment). Penelitian ini dilaksanakan di SMK Negeri 2 Watampone Tahun ajaran 2014/2015.

2. Desain Penelitian

Desain penelitian ini adalah desain faktorial yang dikategorikan sebagai desain faktorial 2 x 3 seperti terlihat pada Tabel 3:

Tabel 3. Desain Faktorial 2 x 3

\begin{tabular}{cccc}
\hline $\begin{array}{c}\text { Gaya } \\
\text { belajar } / \\
\text { model } \\
\text { pembelaja } \\
\text { ran }\end{array}$ & $\begin{array}{c}\text { Visu } \\
\text { al } \\
(\mathbf{B 1})\end{array}$ & $\begin{array}{c}\text { Auditor } \\
\text { ial (B2) }\end{array}$ & $\begin{array}{c}\text { Kinestet } \\
\text { ik (B3) }\end{array}$ \\
\hline $\begin{array}{c}\text { Inquiri } \\
\text { (A1) }\end{array}$ & $\mathrm{A}_{1} \mathrm{~B}_{1}$ & $\mathrm{~A}_{1} \mathrm{~B}_{2}$ & $\mathrm{~A}_{1} \mathrm{~B}_{3}$ \\
$\begin{array}{c}\text { Kooperatif } \\
\text { Tipe } \\
\begin{array}{c}\text { Artikulasi } \\
(\mathrm{A} 2)\end{array}\end{array}$ & $\mathrm{A}_{2} \mathrm{~B}_{1}$ & $\mathrm{~A}_{2} \mathrm{~B}_{2}$ & $\mathrm{~A}_{2} \mathrm{~B}_{3}$ \\
\hline
\end{tabular}

3. Variabel Penelitian

Variabel dalam penelitian ini ada 2 yaitu variabel bebas dan variabel terikat. Variabel bebas manipulatif adalah model pembelajaran (inkuiri dan kooperatif tipe artikulasi), variabel bebas atributif adalah gaya belajar, dan variabel terikat adalah kemampuan berpikir kritis.

4. Populasi dan Sampel

Populasi pada penelitian ini adalah peserta didik kelas X SMK Negeri 2 Watampone semester genap tahunajaran 2014/2015 yang terdiri dari 9kelas dengan jumlah peserta didik sebanyak 288. Dari 
hasil pengambilan sampel terpilih kelas eksperimen adalah kelas jurusan teknik instalasi listik, untuk kelas eksperimen yang menggunakan model pembelajaran inquri terpilih kelas $\mathrm{X}$ TITL 2 dan yang menggunakan model pembelajaran kooperatif tipe artikulasi terpilih kelas $\mathrm{X}$ TITL 1.

5. Teknik Pengambilan Sampel

Pengambilan sampel dilakukan dengan dengan sampling purposive sebanyak dua kali. Pertama untuk menentukan jurusan, dan kelas yang dipilih sebagai kelas eksperimen adalah kelas jurusan teknik instalasi listik. Kedua untuk menentukan kelas eksperimen yang menggunakan model pembelajaran inquri dan yang menggunakan model pembelajaran kooperatif tipe artikulasi berdasarkan hasil angket gaya belajar peserta didik.

6. Prosedur Penelitian

Prosedur pada penelitian ini ada 3 tahap yaitu tahap persiapan, tahap pelaksanaan, dan tahap akhir.

7. Teknik Pengumpulan Data

Data angket gaya belajar diberikan sebelum pertemuan pertama pembelajaran, data kemampuan berpikir kritis peserta didik melalui pemberian pretest dan postestdengan bentuk soal adalah essay.

8. Analisis Data

Analsis data menggunakan analisis statistik deskriptif dan analisis statistik inferensial. Analisis statistik deskriptif meliputi nilai rata-rata (mean), median, standar deviasi, skor tertinggi, dan terendah.

Untuk analisis inferensial meliputi pertama, uji prasyarat yaitu uji normalitas menggunakan analisis One-SampleKolmogorov-Smirnov Test, uji homogenitas menggunakan Levene's Test. Kedua, uji hipotesis menggunakan ANAVA 2 jalur (Analisis varians). Analisis data diolah dengan bantuan program SPSS 20.

Hipotesis statistik pada penelitian ini adalah sebagai berikut:

Hipotesis I:

$$
\begin{aligned}
& \mathrm{H}_{0}: \mu \mathrm{A}_{1}=\mu \mathrm{A}_{2} \\
& \mathrm{H}_{1}: \mu \mathrm{A}_{1} \neq \mu \mathrm{A}_{2}
\end{aligned}
$$

Hipotesis II:
$\mathrm{H}_{0}: \mu \mathrm{B}_{1}=\mu \mathrm{B}_{2}=\mu \mathrm{B}_{3}$

$\mathrm{H}_{1}: \mu \mathrm{B}_{1}=\mu \mathrm{B}_{2} \neq \mu \mathrm{B}_{3}$ atau $\mu \mathrm{B}_{1} \neq \mu \mathrm{B}_{2}=$ $\mu B_{3}$ atau $\mu B_{1} \neq \mu B_{3}=\mu B_{2}$

Hipotesis III:

$\mathrm{H}_{0}: \mu\left(\mathrm{A}_{1} \mathrm{~B}_{1}-\mathrm{A}_{2} \mathrm{~B}_{1}\right)=\mu\left(\mathrm{A}_{1} \mathrm{~B}_{2}-\mathrm{A}_{2} \mathrm{~B}_{2}\right)=$ $\mu\left(\mathrm{A}_{1} \mathrm{~B}_{3}-\mathrm{A}_{2} \mathrm{~B}_{3}\right)$

$\mathrm{H}_{1}$ : paling sedikit ada satu selisih ratarata kelompok yang berbeda.

\section{HASIL DAN PEMBAHASAN}

Data yang diperoleh dalam penelitian ini adalah kemampuan berpikir kritis peserta didik pada materi eletrolit dan non elektrolit.

Hasil pengujian normalitas data dengan analisis One-Sample-KolmogorovSmirnov Test diperoleh nilai signifikansi $(\alpha)$ $=0.20$. Hal ini menunjukkan bahwa data penelitian terdistribusi normal, karena nilai $\alpha$ $>0.05$.

Hasil pengujian homogenitas dengan menggunakan Levene's Testdiperoleh nilai adari analisis yaitu 0.98 , karena signifikansi $(\rho)$ yang diperoleh lebih besar dari $\alpha=0,05$ maka data tersebut homogen.

Pengaruh model pembelajaran dan gaya belajar terhadap kemampuan berpikir kritis kimia peserta didik secara operasional dapat diketahui melalui perbedaan kemampuan berpikir kritisdari setiap kelompok perlakuan. Adanya perbedaan kemampuan berpikir kritis kimia peserta didik pada setiap perlakuan sebagai akibat dari hasil manipulasi variabel bebas (model pembelajaran dan gaya belajar) menunjukkan bahwa variabel bebas mempengaruhi variabel terikat. Hasil pengujian hipotesis I, II dan III secara detail disajikan pada tabel 4:

\section{Tabel 4 Hasil Pengujian Statitistik} Inferensial

Tests of Between-Subjects Effects

Dependent Variable

$\begin{array}{lcccc}\text { Source } & \text { Df } & \begin{array}{c}\text { Mean } \\ \text { Square }\end{array} & \text { F } & \text { Sig. } \\ \begin{array}{l}\text { Model } \\ \text { pembelaja }\end{array} & 2 & 0.92 & 0.001 & 0.97 \\ \begin{array}{l}\text { ran } \\ \text { Gaya }\end{array} & 1 & 430.71 & 6.27 & 0.004\end{array}$




\begin{tabular}{lllll}
\hline Belajar & & & & \\
Gaya & 2 & 224.03 & 3.26 & 0.048 \\
Belajar*m & & & & \\
odel & & & & \\
pembelaja & & & & \\
ran & & & & \\
\hline
\end{tabular}

Berdasarkan Tabel 4 terlihat bahwa signifikansi yang diperolehuntuk hipotesis I lebih besar dari $\alpha=0,05$ berarti $\mathrm{H}_{\mathrm{o}}$ diterima dan $\mathrm{H}_{1}$ ditolak artinya tidak terdapat perbedaan kemampuan berpikir kritis kimia antara peserta didik yang diajar dengan menggunakan model pembelajaraninkuiri dengan peserta didik yang diajar dengan menggunakan model pembelajarankooperatif tipe Artikulasi pada materi pokok larutan elektrolit dan non elektrolit di kelas X SMK Negeri 2 Watampone.

Pada Tabel 4 juga terlihat bahwa signifikansi yang diperoleh,lebih kecil dari $\alpha$ $=0,05$ untuk hipotesis II sehingga $\mathrm{H}_{\mathrm{o}}$ ditolak dan $\mathrm{H}_{1}$ diterima artinya terdapat perbedaan kemampuan berpikir kritis kimia antara peserta didik yang memiliki gaya belajar visual, auditorial dan kinestetik pada materi pokok larutan elektrolit dan non elektrolit di kelas X SMK Negeri 2 Watampone.

Sementara itu, hasil uji Post Hoc Tuckey HSD menunjukkan bahwa kemampuan berpikir kritis peserta didik yang memiliki gaya belajar kinestetik lebih tinggi dibandingkan dengan peserta didik yang memiliki gaya belajar visual dan auditorial, sedangkan kemampuan berpikir kritis peserta didik dengan gaya belajar visual sama dengan peserta didik yang memiliki gaya belajar audiotrial.

Data pada Tabel 4 juga menunjukkan bahwa signifikansi untuk hipotesis IIIlebih kecil dari $\alpha=0,05$ sehingga $\mathrm{H}_{\mathrm{o}}$ ditolak dan $\mathrm{H}_{1}$ diterima artinyaterdapat perbedaan kemampuan berpikir kritis antara peserta didik yang memiliki gaya belajar kinestetik, visual, dan auditori yang diajar pada model pembelajaran inkuiri dengan kemampuan berpikir kritis antara peserta didik yang memiliki gaya belajar kinestetik, visual, dan auditori yang diajar pada model model pembelajaran kooperatif tipe artikulasipada materi pokok larutan elektrolit dan non elektrolit di kelas $\mathrm{X}$ SMK Negeri 2 Watampone.

Hasil analisis dengan uji Post Hoc Tuckey HSD menunjukkan bahwa interaksi antara gaya belajar dan model pembelajaran, signifikansi kemampuan berpikir kritis kimia peserta didik yang bergaya belajar kinestetik jika dibandingkan dengan signifikansi kemampuan berpikir kritis kimia peserta didik yang bergaya belajar auditorial dan visual, lebih kecil dari nilai $\alpha$ $=0,05$.

Hipotesis ketigajuga dapat dijelaskan dengan grafik seperti pada Gambar 1 . Interaksi terjadi karena terdapat perpotongan garis antarainkuiridengan kooperatif tipe artikulasi.Pada gambargrafik tampak adanya perpotongan garis maka dapat disimpulkan bahwaterdapat interaksi antara model pembelajaran dengan gaya belajardalam mempengaruhi kemampuan berpikir kritis kimia peserta didik.

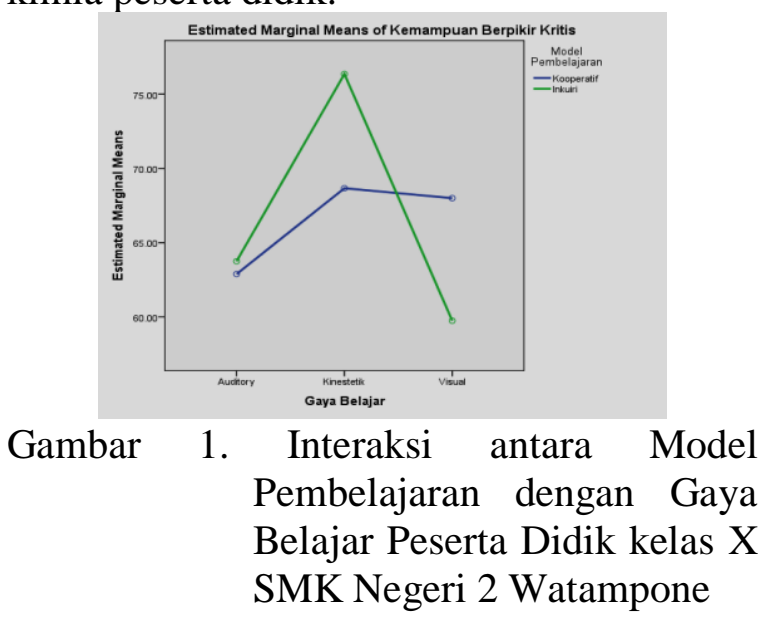

Hasil pengujian hipotesis I juga didukung oleh deskripsi ketuntasan indikator dan hasil pengamatan psikomotorik. Deskripsi tingkat ketuntasan indikator menunjukkan bahwa nilai rata-rata tingkat ketuntasan indikator kelas yang menggunakan model pembelajaran inkuiri hampir sama dengan kelas yang menggunakan model pembelajaran kooperatif tipe artikulasi. Selain itu data hasil pengamatan psikomotorik menunjukkan bahwa nilai rata-rata hasil pengamatan peserta didik pada kelas yang menggunakanmodel pembelajaran inkuiri 
hampir sama dengan kelas yang menggunakan model pembelajaran kooperatif tipe artikulasi.

Model pembelajaran inkuiri memberikan kesempatan yang luas bagi peserta didik untuk mecari dan menemukan sendiri apa yang dibutuhkannya. Pada pelaksanaanya peserta didik mendapatkan informasi melalui eksperimen yang dilakukan, sehingga dapat memecahkan permasalahan yang telah dirumuskan secara bersama, dengan demikian dapat mengembangkan kemampuan berpikir peserta didik.

Model pembelajaran kooperatif tipe artikulasi juga dapat meningkatkan kemampuan berpikir kritis.Model ini sangat membantu peserta didik memahami materi yang sedang mereka pelajari, karena materi pelajaran tidak hanya dijelaskan oleh guru, melainkan dijelaskan kembali oleh teman pasangannya dan setiap peserta didik memiliki kesempatan untuk menjelaskan kembali yang telah dipahami. Hal ini juga melatih peserta didik mengkonstruk pengetahuannya sendiri. Walaupun model pembelajaran inkuri dan kooperatif tipe artikulasi memiliki sintaks yang berbeda, tetapi kedua model ini sama-sama dapat meningkatkan kemampuan berpikir peserta didik, karena dalam proses pelaksanaannya kedua model ini melatih peserta didik untuk mengembangkan kemampuannya.

Pada model inkuiri kemampuan berpikir peserta didik dikembangkan melalui tahapan menemukan jawaban dari permasalah yang ada sedangkan pada model artikulasi melalui kegiatan berdiskusi bersama teman pasangan dan penjelasan dari guru. Sejalan dengan hasil penelitian Hasmah (2012) bahwa model pembelajaran kooperatif Tipe STAD dan model pembelajran langsung tidak mempengaruhi kemampuan berpikir kritis mahasiswa pada materi kimia listrik, serta hasil penelitian Mustafa (2014) bahwa selisih kemampuan berpikir kritis peserta didik yang diajar dengan model pembelajaran inkuiri tidak terlalu jauh dengan kemampuan berpikir kritis peserta didk yang diajar dengan model pembelajaran berbasis masalah, kedua model pembelajaran tersebut mengaktifkan peserta didik dalam proses pembelajaran.

Pada hasil pengujian hipotesis II, deskripsi kemampuan berpikir kritis peserta didik menunjukkan bahwa nilai rata-rata peserta didik yang memiliki gaya belajar visual, auditorial dan kinestetik berbeda antara satu dengan yang lain. Nilai rata-rata kemampuan berpikir krits untuk peserta didik yang memiliki gaya belajar kinestetik lebih tinggi dibandingkan dengan nilai ratarata peserta didik yang memiliki gaya belajar auditorial dan visual. .

Gaya belajarmerupakan kunci untuk mengembangkan kinerja dalam pekerjaan, sekolah,dan dalam situasi antar pribadi. Dengan begitu gaya belajar akanmempengaruhi seseorang dalam menyerap dan mengolah informasi sehinggaakan mempengaruhi prestasi yang dicapai. Peserta didik akan dapat belajar dengan baik dan kemampuan berpikir kritisnya baik, apabila ia mengerti gaya belajarnya.

Deskripsi kemampuan berpikir kritis peserta didik dan nilai rata-rata ketuntasan indikator diperkuat oleh hasil pengujian hipotesis II yang menunjukkan bahwa terdapat pengaruh gaya belajar terhadap kemampuan berpikir kritis peserta didik pada materi pokok larutan elektrolit dan non elektrolit di kelas X SMK Negeri 2 Watampone.

Gaya belajar peserta didik memberikan kecenderungan untuk mengadaptasi strategi tertentu dalam belajarnya sebagai bentuk tanggung jawabnya untuk mendapatkan satu pendekatan belajar yang sesuai dengan tuntutan belajar. Selain itu, motivasi belajar merupakan salah satu faktor yang dapat meningkatkan kemampuan berpikir kritis, karena peserta didik akan belajar dengan sungguh-sungguh apabila memiliki motivasi yang tinggi.

Hasil pengujian hipotesis II didukung oleh data hasil pengamatan psikomotorik yang menunjukkan bahwa peserta didik yang memiliki gaya belajar visual, auditorial 
dan kinestetik berbeda. Nilai rata-rata psikomotorik peserta didik yang memiliki gaya belajar kinestetik lebih tinggi jika dibandingkan dengan peserta didik yang memiliki gaya belajar visual dan kinestetik.Penilaian psikomotorik ini dikategorikan kedalam tiga kategori yaitu baik, cukup, dan kurang. Peserta didik yang memiliki gaya belajar kinestetik pada kategori baik sebesar $52.17 \%$, gaya belajar visual sebesar $18.18 \%$ sedangkan gaya belajar auditorial 0\%.Hal ini menandakan bahwa peserta didik yang gaya belajarnya kinestetik memiliki motivasi yang tinggi untuk belajar, karena individu yang memiliki motivasi yang tinggi terhadap suatu aktivitas, akan memberikan perhatian yang lebih tinggi dan lebih aktif dibandingkan dengan individu yang memiliki motivasi yang rendah.

Sementra itu, hipotesis III mengenai interaksi antara model pembelajaran dan gaya belajar berpengaruh terhadap kemampuan berpikir kritis peserta didik kelas X SMK Negeri 2 Watampone.

Pada kelas yang menggunakan model pembelajaran inkuiri nilai kemampuan berpikir kritis peserta didik berdasarkan gaya belajar jika diurut dari yang tertinggi ke yang terendah yaitu kinestetik, auditori dan visual, sedangkan pada kelas yang menggunakan model pembelajaran kooperatif tipe artikulasi yaitu kinestetik, visual dan auditori. Hal ini menunjukkan bahwa ada interaksi antara gaya belajar dengan model pembelajaran. Gaya belajar kinestetik cocok dengan kedua model pembelajaran yang digunakan, hal ini karena pada kedua model pembelajaran tersebut memberikan kesempatan kepada peserta didik untuk berperan aktif selama pembelajaran berkooperatif tipe artikulasi yang sangat cocok dengan peserta didik yang memiliki gaya belajar ini yang menyukai kegiatan yang menyibukkan.

Model pembelajaran inkuiri selain cocok untuk gaya belajar kinestetik juga cocok untuk peserta didik dengan gaya belajar auditori, hal ini karena pada model pembelajaran kooperatif tipe artikulasi nilai kemampuan berpikir kritis peserta didik lebih rendah. Pada pelaksaannya model pembelajaran kooperatif tipe artikulasi memberikan kesempatan kepada peserta didik yang memiliki gaya belajar auditori lebih besar karena peserta didik dapat membicarakan apa yang dipelajari, tetapi kemampuan peserta didik dalam mengutarakan pendapat masih kurang dan kaku hal ini menyebabkan peserta didik dengan gaya belajar auditori agak sulit mehami materi pada kelas kooperatif sedangkan pada model inkuiri peserta didik lebih santai dalam berdiskusi sehingga lebih mudah memahami materi pelajaran. Perbedaan hasil kemampuan berpikir kritis peserta didik dengan gaya belajar auditori pada model kooperatif dan inkuiri tidak terlalu jauh berbeda.

Peserta didik dengan gaya belajar visual lebih cocok menggunakan model pembelajaran kooperatif tipe artikulasi, karena pada model ini peserta didik dapat melihat secara kooperatif tipe artikulasi apa yang sedang dibicarakan guru melalui demonstrasi dan persentasi yang ditampilkan oleh guru. Selain itu saat pasangan diskusi menjelaskan memberikan daya tarik tersendiri bagi peserta didik ini sehingga lebih memperhatikan apa yang disampaikan pasangannya.

Hasil pengujian hipotesis III didukung oleh data hasil penilaian psikomotorik yang menunjukkan bahwa peserta didik yang memiliki gaya belajar visual, auditorial dan kinestetik berbeda. Pada kelas yang menggunakan model pembelajaran inkuiri, nilai rata-rata psikomotorik peserta didik yang memiliki gaya belajar kinestetik lebih tinggi jika dibandingkan dengan peserta didik yang memiliki gaya belajar auditorial dan kinestetik, sedangkan pada kelas yang menggunakan model pembelajaran kooperatif tipe artikulasi, terlihat bahwa peserta didik yang memiliki gaya belajar visual lebih tinggi jika dibandingkan dengan peserta didik yang memiliki gaya belajar auditorial, peserta didik dengan gaya belajar kinestetik lebih tinggi dari gaya belajar visual dan auditori. Hal ini sejalan 
dengan hasil penelitian Ahriani (2013) bahwa ada selisih perbedaan interaksi antara model pembelajaran dan gaya belajar peserta didik di kelas X SMK Negeri 2 Bantaeng.

\section{KESIMPULAN}

Simpulan yang dapat ditarik dari hasil penelitian dan pembahasan yaitu tidak ada pengaruh model pembelajaran inkuiri dan model pembelajaran kooperatif tipe Artikulasi terhadap kemampuan berpikir kritis peserta didik di kelas X SMK Negeri 2 Watampone pada materi pokok larutan elektrolit dan non elektrolit, ada pengaruh gaya belajar kinestetik, visual dan auditorialterhadap kemampuan berpikir kritis peserta didik di kelas X SMK Negeri 2 Watampone pada materi pokok larutan elektrolit dan non elektrolit, ada pengaruh interaksi antara model pembelajaran dan gaya belajar terhadap kemampuan berpikir kritis peserta didikdi kelas X SMK Negeri 2 Watamponepada materi pokok larutan elektrolit dan non elektrolit, rata-rata kemampuan berpikir kritis peserta didik yang diajar dengan model pembelajaran inkuiri dan model pembelajaran kooperatif tipe Artikulasi masing-masing 75.78 dan 66.40, rata-rata kemampuan berpikir kritis peserta didik yang memiliki gaya belajar kinestetik, visual dan auditori berturut-turut yaitu 73.34, 65.00 dan 63.15, model pembelajaran inkuiri cocok untuk peserta didik dengan gaya belajar kinestetik, sedangkan model pembelajaran kooperatif tipe artikulasi cocok untuk peserta didik dengan gaya belajar visual.

\section{DAFTAR PUSTAKA}

Ahriani, F. (2013).Pengaruh Model Pembelajaran Kooperatif dan Gaya Belajar terhadap Hasil Belajar Kimia Peserta Didik Kelas X SMK Negeri 2 Bantaeng. Thesis.Tidak diterbitkan.Makassar : Program Pasca Sarjana UNM.

De Porter, dan Hernacki., 1992, Quantum Learning.Kaifa, Bandung.
Gilakjani, A. 2012.Visual, Auditory, Kinaesthetic Learning Style and Their Impact on English Language Teaching.Journal of Studies in Education, 2(1), 104-113.

Gufron dan Risnawita. 2010. Gaya Belajar, Kajian Teoritik. Yogyakarta. Pustaka Belajar.

Hasmah. 2012. Pengaruh Model Pembelajaran dan Kemampuan Awal Terhadap Kemampuan Berpikir Kritis Mahasiswa Akademik Teknik Elektromedik Muhammadiyah Makassar, Studi Pada Mata Kuliah Dasar Materi Pokok Kimia Listrik. Tesis. Tidak diterbitkan : Makassar: Program Pasca Sarjana UNM.

Hasruddin. 2009. Memaksimalkan Kemampuan Berpikir Kritis Melalui Pendekatan Kontekstual. Jurnal Tabularasa PPs UNIMED, 6(1) 48-60.

Mustafa, M. (2014). Pengaruh Model Pembelajaran dan Kemampuan Awal Terhadap Kemampuan Berpikir Kritis Peserta Didik Kelas XI IPA SMAN 1 Barru, Pada Materi Pokok Hasil Kali Kelarutan.Tesis.Tidak diterbitkan. Makassar: Program Pasca Sarjana UNM.

Pritchard, A. 2009.Ways of Learning, Learning Theories and Learning Styles in The Classroom. New York. Routledge Taylor \& Francis Group.

Sanjaya, W. 2006.Strategi Pembelajaran

Berorientasi Standar Proses

Pendidikan. Jakarta: Kencana Prenadamedia Group.

Slameto, 2003.Belajar dan Faktor-faktor yang Mempengaruhinya. Jakarta: Rineka Cipta.

Suyanti, R.D. 2007. Strategi Pembelajaran Kimia. Yogyakarta: Graha Ilmu.

Suyatno. 2009. Menjelajah Pembelajaran Inovatif. Sidoarjo: Masmedia Buana Pustaka. 